\title{
Kisspeptin'in Gelişimsel Döneme Bağlı Olarak Dişi Sıçanlarda Medial Preoptik Bölgede in Vitro Noradrenalin Salıverilmesi Üzerine Etkisi ${ }^{*}$
}

\author{
Zülfiye GÜL ${ }^{1}$, Rıfat Levent BÜYÜKUYSAL ${ }^{2}$ \\ 1 Bahçeşehir Üniversitesi Tıp Fakültesi, Tıbbi Farmakoloji Anabilim Dalı, İstanbul. \\ 2 Bursa Uludağ Üniversitesi Tıp Fakültesi, Tıbbi Farmakoloji Anabilim Dalı, Bursa.
}

\section{ÖZET}

Üçüncü ventrikülün rostral periventriküler bölgesinde lokalize olan kisspeptin nöronlarının, ovulasyon öncesi LH salıverilmesinden sorumlu olan GnRH nöronlarının major stimülatörü olduğu son yıllarda yapılan çalışmalar ile ortaya konmuștur. GnRH salıverilmesinin bir diğer ana modülatörü ise noradrenerjik sistemdir. Kisspeptinerjik ve noradrenerjik nöronların medial preoptik bölgedeki (MPB) yerleşimleri çok yakınlık göstermekle birlikte, bu iki sistem arasındaki ilişkinin yapılacak çalışmalar ile aydınlatılmasına ihtiyaç duyulmaktadır. Yapılan bu çalışma gelişim dönemi farklı dişi Sprague Dawley sıçanların MPB'sinden hazırlanan beyin dilimleri kullanılarak kisspeptinin noradrenalin (NA) salıverilmesi üzerine direk etkisinin olup olmadığını ortaya koymak amacı ile yapılmıştır. Oksijenlenmiş Krebs solüsyonu içeren inkübasyon kuyucuklarına yerleștirilen dilimler preinkübasyon dönemi ardından 60 dakika boyunca kisspeptin (40 ve $400 \mu \mathrm{M})$ ile inkübe edildi. İnkübasyon periyodu sonrasında inkübasyon ortamı salınan NA düzeylerinin belirlenmesi amacıyla kullanıldı. Salıverilmenin $\mathrm{Ca}^{2+}$ ile ilişkisini incelemek amacıyla $\mathrm{Ca}^{2+}$ suz Krebs solüsyonu ve hücre dıșı $\mathrm{Ca}^{2+}$ şelasyonu için $400 \mu \mathrm{M}$ BAPTA kullanıldı. Prepubertal, adölesan ve yetişkin dişi sıçanların MPB'den elde edilen dilimlerin 40 ve $400 \mu \mathrm{M}$ kisspeptin ile inkübasyonu prepubertal dönemdeki dilimlerden NA salıverilmesini etkilemezken, adölesan ve yetişkin sıçanlarda ise salıverilmenin anlamlı olarak arttığı gözlendi. $\mathrm{Ca}^{2+}$ un ortamdan uzaklaștırılmasının kisspeptin kaynaklı NA salıverilmesinde anlamlı bir düşüşe $(\mathrm{p} \prec 0.05)$ neden olması veziküler salım mekanizmasının ekstrasellüler $\mathrm{Ca}^{+2}$ iyonlarına bağımlı olduğunu göstermiștir. Kisspeptinin NA salıverilmesini direkt olarak uyarabildiğgini gösteren bu bulgular, söz konusu peptidin NA salıverilmesi üzerinden GnRH salıverilmesini indirekt olarak modüle edebileceğini düşündürmektedir.

Anahtar Kelimeler: Kisspeptin. Noradrenalin. GnRH. Medial preoptik alan. Beyin dilimleri.

Kisspeptin Stimulates In Vitro Noradrenaline Release in Medial Preoptic Area of the Female Rats Depending on Developmental Stage

\begin{abstract}
Kisspeptin neurons localized in the rostral periventricular area of the third ventricle are considered to provide a major stimulatory input to the GnRH neuronal network which is responsible for triggering the preovulatory LH surge. Noradrenaline (NA) is one of the main modulators of GnRH release. Although NA fibers are found in close opposition to kisspeptin neurons, interaction between kisspeptin and NA neurons needs to be clarify. Thus, present study was undertaken to determine whether kisspeptin can directly regulate NA release from brain slices prepared from medial preoptic area (MPOA) of the rats. Brain slices prepared from female prepubertal, adolescents or adult Sprague Dawley rats were placed incubation wells containing oxygenated Krebs. After preincubation period, slices were incubated with two different concentrations of kisspeptin $(40$ and $400 \mu \mathrm{M})$ for $60 \mathrm{~min}$. At the end of kisspeptin incubation, incubation medium was used for determination of NA released from the slices. When used $\mathrm{Ca}^{+2}$-free medium, $400 \mu \mathrm{M}$ of BAPTA was also added into the medium to chelate the extracellular $\mathrm{Ca}^{+2}$. Incubation of the brain slices prepared from MPOA of the adolescent and adult female rats with 40 and $400 \mu \mathrm{M}$ of kisspeptin caused significant increase in NA release, unlike prepubertal rat. Since removal of the $\mathrm{Ca}^{+2}$ from the medium caused significant decline in kisspeptininduced NA release ( $\mathrm{p}<0.05)$, a vesicular release mechanism seems to be likely involved. The results presented here probably indicate that in addition to direct effect of kisspeptin, it may also modulate GnRH release indirectly by increasing NA release from MPOA of hypothalamus.
\end{abstract} Key Words: Kisspeptin. Noradrenaline. GnRH. Medial preoptic area. Brain slices.

Geliş Tarihi: 17.Nisan.2020

Kabul Tarihi: 07.Ağustos.2020

Dr. Zülfiye GÜL

Bahçeşehir Üniversitesi Tıp Fakültesi, Tıbbi Farmakoloji Anabilim Dalı, İstanbul.

Tel: 05413841268

E-posta: zulfiye.gul@med.bau.edu.tr
* " "17th European Congress of Neuroendocrinology" kongresinde (Milano/Italya, 2015) poster bildiri olarak sunulmuştur.

Yazarların ORCID ID Bilgisi:

Zülfiye GÜL: 0000-0002-8872-0074

Rıfat Levent BÜYÜKUYSAL: 0000-0003-0749-2426 


\section{Z. Gül ve R.L. Büyükuysal}

Hipotalamo-hipofizer-gonadal aks, üreme yeteneğinin kazanılması ve sürdürülmesine aracılık eden ve diğer sistemlerle kompleks ilişkileri olan merkezi bir sistem olarak bilinmektedir ${ }^{1}$. Pubertede üreme sistemi aktivasyonunun nöroendokrin kontrolünde rol alan başlıca hormonlar pulsatil salgılanan gonadotropin salıverici hormon $(\mathrm{GnRH})$, folikül stimüle edici hormon $(\mathrm{FSH})$ ve lüteinleştirici hormondur $(\mathrm{LH})^{1}$. GnRH sistemi, hormon salıverilmesini inhibitör ve eksitatör sinyallerle düzenleyen ve hipotalamusun farklı bölgelerinde kümelenmiş nöronlardan oluşmaktadır ${ }^{1}$. Puberte sırasında bu sistemin nasıl aktive olduğu, uyarıcı veya inhibitör sistemler arasındaki ilişki uzun yıllar araşt1rılmış, ancak aydınlatılamayan yönleri ile popüler bir araştırma alanı olma özelliğini korumuştur. Son yıllarda yapılan çalışmalar ile, GnRH etkinliğinin hipotalamustan salıverilen kisspeptinler tarafindan regüle edildiği saptanmış ve kisspeptinin puberte başlangıcındaki tetikleyici mekanizmanın kritik bir bileşeni olduğu ortaya konmuştur ${ }^{2-6}$.

Kisspeptinler, Kiss-1 geni tarafindan transkribe edilen öncül bir proteinden türeyen, puberte ve fertilitede önemli roller aldıkları yapılan çalışmalarla gösterilen, farklı aminoasit uzunluklarındaki peptidler olarak bilinmektedirler $^{3-5}$. Hipotalamusta biri rostral periventriküler alanda (RP3V) diğeri arkuat çekirdekte olmak üzere iki ana kisspeptin nöron popülasyonu bulunur $^{7}$. Hem RP3V'daki hem de ARC'daki kisspeptin nöronlarının doğrudan $\mathrm{GnRH}$ nöronlarına projeksiyon yaptıkları gösterilmiştir ${ }^{8,9}$. Kisspeptinin ve reseptörü olan G-protein reseptör 54'ün (GPR54) üreme fonksiyonlarının kazanılması ve bu fonksiyonların sürdürülmesine aracılık ettiği literatürde birçok çalışma ile rapor edilmiştir ${ }^{3}$. Kisspeptin reseptörü GPR54 ile ilgili insan ve hayvanlarda yapılan çalışmalarda, bu reseptör fonksiyonunun kaybına neden olan mutasyonların pubertal gelişim geriliği ve üreme fonksiyon kaybı ile karakterize hipogonadotropik hipogonadizme neden olduğu tespit edilmiştir; bu bulgular GPR54 reseptörünün puberte döneminde normal GnRH aktivitesi için gerekli olduğunu göstermektedir ${ }^{2,6,7}$. GPR54 -/- farelerde yapılan bir çalışmada pubertal gelişim geriliği ve üreme fonksiyon kaybı görülmesine rağmen, GnRH nöronlarının median eminense projeksiyon yaptıkları ve normal morfolojiye sahip oldukları gösterilmiş ve kisspeptin-GPR54 sisteminin, GnRH sistemi üzerinde yer alacak bir mekanizma olarak devreye girebileceği yorumu yapılmıştır ${ }^{10}$. Bu bilgilere ek olarak kisspeptinin sıçanlarda ve primatlarda $\mathrm{GnRH}$ antagonistleri ile geri döndürülebilen $\mathrm{LH}$ ve $\mathrm{FSH}$ düzeylerini $\operatorname{arttırdığg} 1{ }^{11,12}$ ve prepubertal dişilerde kispeptinin ovulasyonu indüklediği de bildirilmiştir ${ }^{13}$.

Alfa adrenerjik reseptör antagonistleri ile tedavi altındaki hastalarda gözlenen önemli bir bulgu, GnRH salgılanmasının bozulması ve buna bağlı olarak FSH ve $\mathrm{LH}$ düzeylerinin azalmasıdır ${ }^{14-17}$. Bu bulgular ile birlikte noradrenalin (NA) nöronlarının hipolatalamusta $\mathrm{GnRH}$ nöronlarının terminalleriyle aynı bölgede bulunduğunun gösterilmesi sonrası GnRH ve NA arasında salıverilme miktarı ve ritmi açısından yakın bir ilişki olduğu da gösterilmiştir ${ }^{18-22}$. Diğer taraftan NA geri alım inhibitörü desmetilimipramin (DMI) kullanılarak yapılan bir mikrodiyaliz çalışmasında, söz konusu ilacın hipotalamusta GnRH ve NA salıverilmesini benzer aralıklarla arttırdığı rapor edilmiştir ${ }^{23}$

GPR54-null farelerde yapılan bir çalışmada, intraserebroventriküler NMDA enjeksiyonu ile düşük olan LH düzeylerinde kontrol düzeylerine varan bir artış gözlenmiş ve immünohistokimyasal analizler ile bu artışa medial preoptik alandaki (MPOA) katekolaminerjik nöronların aktivasyonunun aracılık ettiği bulunmuştur ${ }^{24}$. Kisspeptin nöronlarının, noradrenerjik ve GnRH nöronları ile aynı bölgede bulunması ve GnRH salıverilmesini doğrudan etkilemesi, kisspeptin ve NA arasında bir ilişki olabileceğini düşündürmekle birlikte, kisspeptin salıverilmesinin ve/veya kisspeptin reseptör aktivasyonunun söz konusu bölgede NA düzeylerini nasıl etkilediği bilinmemektedir. Bu çalışma ile kisspeptinin MPOA'da NA salıverilmesi üzerine direkt bir etkisinin varlığı ve eğer varsa bu etkinin gelişimsel dönem ile ilişkili olup olmadığı araştırılmıştır.

\section{Gereç ve Yöntem}

\section{Materyaller}

Deneylerde kullanılan Kisspeptin-10 Tocris Bioscience (Bristol, UK) firmasından, BAPTA, NA ve albumin Sigma Chem Co firmasindan (St. Louis, MO, USA) temin edilmiştir. Krebs solüsyonu hazırlamada kullanılan kimyasallar ile diğer kimyasallar Carlo Erba Reagents (Val de Reuil, FR) veya Merck firmalarından temin edilmiştir.

\section{Deney Hayvant:}

$\mathrm{Bu}$ çalışmada yapılan deneyler için Uludağ Üniversitesi Hayvan Deneyleri Yerel Etik Kurulu'ndan (HADYEK) 16.02.2016 tarih ve 2016-03/05 numaralı etik kurul onayı alındı. Tüm deneysel çalışmalarda hipogonadal aksın farklı çalıştığı zaman aralıkları göz önünde bulundurularak, henüz efektif çalışmaya başlamadığı için prepubertal (23-25 günlük), çalışmaya yeni başladığı adölesan (35-40 gün) ve düzenli çalışmaya devam ettiği yetişkin (2-3 aylık) dişi Sprague Dawley sıçanlar kullanıldı. Uludağ Üniversitesi Deney Hayvanları Yetiştirme Uygulama ve Araştırma Merkezi'nden temin edilen sıçanlar, 1sısı $20-24{ }^{\circ} \mathrm{C}$ olacak şekilde sabit tutulan, 12 saat aydınlık ve 12 saat karanlık (07.00-19.00 arası aydınlık) döngüsüyle çalışan bir ortamda barındırıldı ve herhangi bir su ve yem kısıtlaması yapılmadi. 


\section{Kisspeptin'in Noradrenalin Salıverilmesi Üzerine Etkisi}

\section{Beyin dilimlerinin hazırlanması ve inkübasyonu:}

Dekapitasyon sonrası en kısa sürede çıkartılan beyinler önceden soğutulmuş ve oksijenlendirilmiş ( $\% 95 \mathrm{O}_{2}$ ve $\% 5 \mathrm{CO}_{2}$ ile) fizyolojik Krebs içine alındı. Kullanılan Krebs çözeltisinin kompozisyonu şöyledir (mmol/L): $\mathrm{NaCl} 120, \mathrm{CaCl}_{2} \quad 1.3, \mathrm{MgSO}_{4} \quad 1.2$, $\mathrm{NaH}_{2} \mathrm{PO}_{4} 1.2, \mathrm{KCl} 3.5, \mathrm{NaHCO}_{3} 25$ ve $10 \mathrm{mmol} / \mathrm{L}$ glukoz. Hizlı bir şekilde preoptik bölge diseke edildi ve doku dilimleyicisine (McIlwain) yerleştirilerek 0.3 mm kalınlığında dilimlendi. Dilimlenmiş doku, içinde soğuk ve oksijenlenmiş fizyolojik sıvı bulunan petri kabına alınıp ve firça yardımıyla dilimler birbirlerinden ayrıldı. Elde edilen doku dilimleri firça yardımıyla $0.3 \mathrm{ml}$ oksijenlenmiş Krebs içeren ve $37^{\circ} \mathrm{C}$ dereceye ayarlanmış su banyosu içindeki inkübasyon kuyucuklarına, her bir kuyucukta 1 dilim olacak şekilde yerleştirildi $^{25,26}$. Bir sıçandan elde edilen dilimler her gruba n sayısı 1 olarak dağıtıldı ve her deney 7 kez tekrar edildi (her grup için $n=7$ sıçan). Bir saatlik preinkübasyon döneminde, dilimlerin inkübe edildikleri ortam her 15 dakikada bir taze oksijenlenmiş Krebs ile değiştirildi. Denge döneminin ardından aşağıdaki deney protokolleri uygulandı.

\section{Deney Protokolü}

Protokol 1: Prepubertal, adölesan ve yetişkin sıçanlardan hazırlanan preoptik dilimlerde bazal NA salıverilmesinin ve doku NA düzeylerinin incelenmesi

$0.3 \mathrm{ml}$ Krebs içeren inkübasyon kuyucuklarına yerleştirilen dilimler 60 dakikalık pre-inkübasyon döneminin ardından 60 dakika boyunca $0.3 \mathrm{ml}$ Krebs içinde inkübasyona bırakıldı. $\mathrm{Bu}$ sürenin sonunda inkübasyon ortamları salıverilen NA ölçümü için toplandı ve NA oksidasyonunu önlemek için $\mathrm{HClO}_{4}$ ile asitlendirildi (son konsantrasyon 0.4 N). Dokular ise $0.3 \mathrm{ml} 0.4 \mathrm{~N} \mathrm{HClO}_{4}$ içine alınarak homojenize edildi. Homojenatın bir kısmı $(50 \mu \mathrm{l})$ doku total protein ölçümü için kullanılırken, kalan homojenat santrifüj edildi (10 dakika, $12.000 \mathrm{rpm}$ ) ve elde edilen süpernatant doku NA düzeyinin ölçümü için kullanıldı.

Protokol 2: Prepubertal, adölesan ve yetişkin sıçanlardan hazırlanan preoptik dilimlerden NA salıverilmesi üzerine kisspeptidin etkisi:

Çalışmamızda kullanılacak kisspeptin dozunu belirlemek amacıyla değişen kisspeptin dozlarında $(0,1,1$, $10,40,400 \mu \mathrm{M})$ adölesan sıçanlardan elde edilen dilimlerde tarama testi yapıldı ve çalışmanın devaminda etkili bulunan 40 ve $400 \mu \mathrm{M}$ dozlarında kullanıldı. Pre-inkübasyon döneminin ardından dilimler kisspeptin $(40,400 \mu \mathrm{M})$ içeren veya içermeyen ortamda 60 dakika boyunca inkübe edildi. İnkübasyon süresinin bitmesinin ardından dokular $0.4 \mathrm{~N}$ perklorik asit içine alındı. $\mathrm{Bu}$ sürenin sonunda toplanan inkübasyon ortamları ve dokular Protokol 1'de belirtildiği salıverilen ve doku NA düzeylerinin ölçümü için kullanıldı.
Protokol 3: Kisspeptinin preoptik dilimlerde NA sal1verilmesi üzerine etkisinin ekstrasellüler $\mathrm{Ca}^{+2}$ ile ilişkisi:

Protokol 2'de inkübasyon ortamina eklenen kisspeptinin preoptik dilimlerden NA salıverilmesini arttırdığ 1 gösterildikten sonra, bu artışın ekstrasellüler $\mathrm{Ca}^{+2}$ ile bağımlılığı $\mathrm{Ca}^{+2}$ içermeyen ve ekstrasellüler $\mathrm{Ca}^{+2}$ ile şelat oluşturarak onu bağlayan BAPTA (200 $\mu \mathrm{M}$; 1,2-bis(o-aminophenoxy)ethane-N,N,N',N'tetraacetic acid) eklenmiş Krebs kullanılarak test edildi.

\section{Noradrenalin ölçümü}

Dilimlerden salıverilen ve doku NA düzeyleri elektrokimyasal dedektör (Electrochemical cell: Model 5041, Guard cell: Model 5020) bağlantılı yüksek basınçlı sıv1 kromatografisi (ESA, Coulochem 3, Model 530032) sistemi kullanılarak ölçülmüştür. $\mathrm{Bu}$ sistemde mobil faz olarak $150 \mathrm{mM} \mathrm{NaH} \mathrm{PO}_{4}$ tamponu, (1 $\mathrm{mM}$ 1-Octane sulfonik asit, $100 \mu \mathrm{M}$ EDTA, \%15 Metanol), analitik kolon olarak da $\mathrm{C}_{18}$ kolon (ESA $\mathrm{C} 18$ narrowbore) kullanıldı. Sistemde kolon sicaklığ $30{ }^{\circ} \mathrm{C}$ olacak ve mobil faz akış hızı $0,4 \mathrm{ml} /$ dakikaya ayarland1. $\mathrm{HClO}_{4}$ ile asitlendirilmiş inkübasyon ortamları (20 $\mu \mathrm{l})$ ve doku süpernatant örnekleri $(20 \mu \mathrm{l})$ direkt olarak HPLC sistemine enjekte edildi. Kromatografik analiz sonrası elde edilen pikler, $0,4 \mathrm{~N}$ asit içinde hazırlanan ve örneklerle paralel bir şekilde çalışılan standartların pikleri ile karşılaştırılarak miktar tayini yapıldı.

\section{Protein Ölçümü}

Ölçülen NA miktarları total doku proteinine oranlanarak verildi. Total doku protein düzeyi Lowry ve arkadaşlarının $^{46}$ yöntemine göre $50 \mu \mathrm{l}$ doku homojenatı kullanılarak ölçüldü. Protein standartları koyun serum albümini kullanılarak $0,4 \mathrm{~N} \mathrm{HClO}_{4}$ içinde hazırlandı ve doku örnekleriyle birlikte çalışıldı.

\section{Istatistiksel Analizler}

Elde edilen bütün değerler "ortalama \pm standart sapma" şeklinde verildi. İstatistiksel analizler SPSS 22.0 programı kullanılarak yapıldı (SPSS Inc. Chicago, IL, USA). Verilerin normallik analizleri KolmogorovSimirnov Z testi ile gerçekleştirildi. Karşılaştırmalarda One Way ANOVA testi ardından post-hoc testi olarak, Tukey testi kullanıldı. Tüm testlerde istatistiksel anlamlılık değeri $\mathrm{p}<0,05$ olarak kabul edildi.

\section{Bulgular}

Prepubertal, adölesan ve yetişkin slçanlardan hazırlanan preoptik dilimlerden bazal NA sallverilmesi ve doku NA düzeyleri:

Bir saatlik kontrol koşullarında bazal NA salıverilmesi prepubertal siçanlarda $0,2 \pm 0,01 \mathrm{pmol} / \mathrm{mg}$ protein, 


\section{Z. Gül ve R.L. Büyükuysal}

adölesan siçanlarda $0,65 \pm 0,06 \mathrm{pmol} / \mathrm{mg}$ protein, yetişkin siçanlarda ise $1,68 \pm 0,1 \mathrm{pmol} / \mathrm{mg}$ protein bulundu. İstatistiksel olarak karşılaştırıldığında spontan NA salıverilmesinin adölesan $(p<0.05)$ ve yetişkin sıçanlarda $(\mathrm{p}<0.01)$ prepubertal sıçanlara göre anlamlı olarak yüksek olduğu saptandı (Şekil 1A). Doku NA düzeyleri prepubertal ve adölesan siçanlarda sirasi ile $1,79 \pm 0,05$ ve 2,5 $0 \pm 0,3 \mathrm{pmol} / \mathrm{mg}$ protein bulundu $(p>0.05)$. Yetişkin sıçanlarda ölçülen doku NA miktarının ise diğer iki yaş grubundaki sıçanlardan çok daha yüksek olduğu saptandı $(17,3 \pm 1$ $\mathrm{pmol} / \mathrm{mg}$ protein; $\mathrm{p}<0.001$; Şekil 1B).
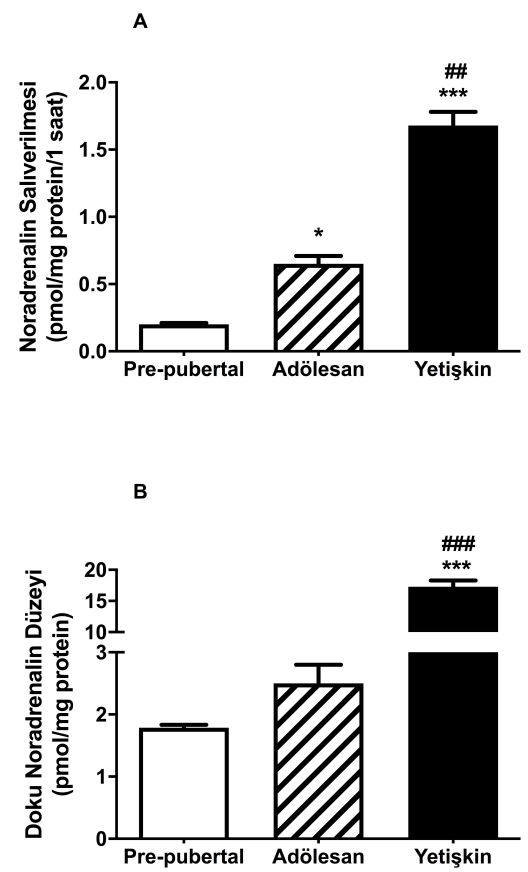

Şekil 1.

Yaşın MPOA'daki NA salvverilmesi (A) ve doku düzeyleri (B) üzerine etkisinin pre-pubertal, adölesan ve yetişkin dişi slçanlarda değerlendirilmesi

Pre-pubertal, adölesan ve yetişkin sıçanlardan hazırlanan beyin dilimlerinin kontrol koşullarında 1 saatlik inkübasyon sonrası ortama salıverilen NA düzeyleri (A) ve inkübasyon sonras1 homojenize edilen dokulardan elde edilen süpernatant doku NA düzeyleri (B) elektrokimyasal detektörlü HPLC aracıllı̆̆ ile ölçüldü. Data ortalama \pm standart hata olarak sunuldu $(\mathrm{n}=7){ }^{*} \mathrm{p}<0.05$, *** $\mathrm{p}<0.001$ prepubertal gruba göre anlaml1; ${ }^{\#} \mathrm{p}<0.01,{ }^{\# \#} \mathrm{p}<0.001$ adölesan gruba göre anlaml1.

Prepubertal, adölesan ve yetișkin sıçanlardan hazırlanan preoptik dilimlerden NA sallverilmesi üzerine kisspeptinin etkisi:

İnkübasyon ortamına eklenen kisspeptin (40 ve 400 $\mu \mathrm{M})$ pre-pubertal sıçanlardan hazırlanan preoptik dilimlerden NA salıverilmesini hafif arttırsa da bu artış istatistiksel olarak anlamlılık seviyesine ulaşmadı (40 $\mu \mathrm{M}$ için 0,29 $\pm 0,05 \mathrm{pmol} / \mathrm{mg}$ protein, $400 \mu \mathrm{M}$ için
$0,39 \pm 0,03 \mathrm{pmol} / \mathrm{mg}$ protein; $\mathrm{p}>0,05$, Şekil $2 \mathrm{~A})$. Doku NA düzeylerinin de NA salıverilmesi ile benzer olarak 40 ve $400 \mu \mathrm{M}$ kisspeptin dozunda bir miktar azaldığ 1 ancak bu azalmanın da anlamlı olmadığı tespit edildi ( $p>0,05$, Şekil 2B).
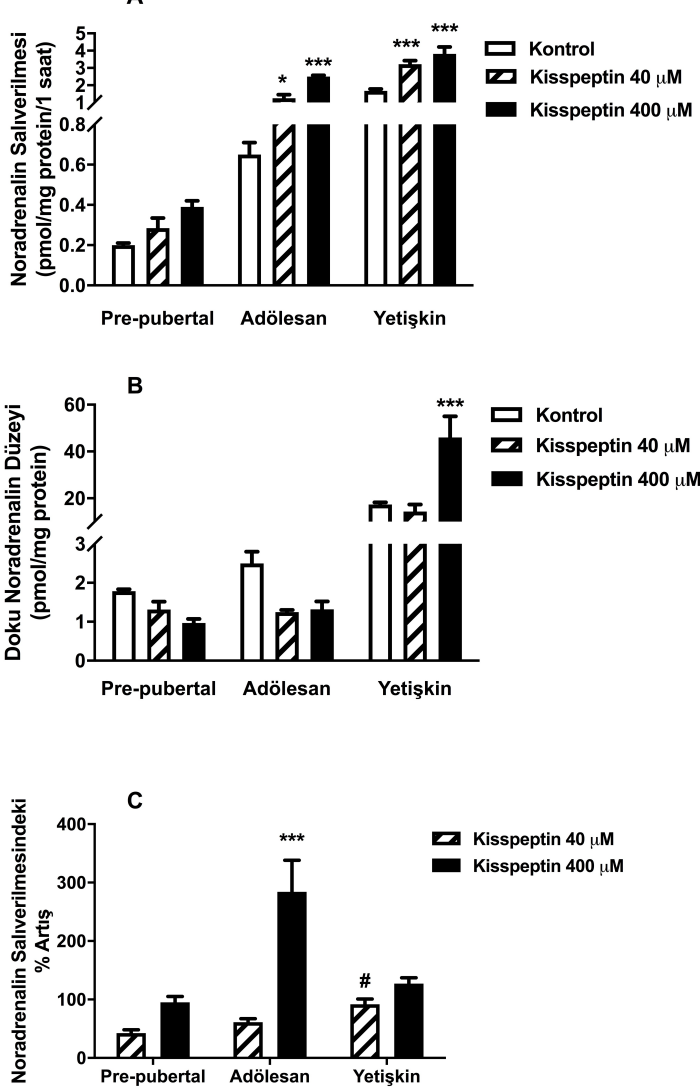

Şekil 2.

Kisspeptin dozlarının MPOA'daki NA salıverilmesi (A), doku düzeyleri (B) ve kontrole göre yüzde sallverilmesi (C) üzerine etkisinin pre-pubertal, adölesan ve yetişkin dişi sıçanlarda değerlendirilmesi

Pre-pubertal, adölesan ve yetişkin sıçanlardan hazırlanan beyin dilimlerinin kisspeptin dozları ile (40 ve $400 \mu \mathrm{M}) 1$ saatlik inkübasyon sonrası ortama salıverilen NA düzeyleri (A) ve inkübasyon sonrası homojenize edilen dokulardan elde edilen süpernatant doku NA düzeyleri (B) elektrokimyasal detektörlü HPLC aracılığı ile ölçüldü. Grupların NA salınım yüzdeleri kontrol NA düzeylerine göre oranlanarak hesapland $1(\mathrm{C})$. Data ortalama \pm standart hata olarak sunuldu $(\mathrm{n}=7) . * \mathrm{p}<0.05, * * * \mathrm{p}<0.001$ kendi kontrol grubuna göre anlaml.

Adölesan sıçanlardan hazırlanan preoptik dilimlerde $40 \mu \mathrm{M}$ konsantrasyonda kisspeptin NA salıverilmesini bazal değeri olan $0,65 \pm 0,06 \mathrm{pmol} / \mathrm{mg}$ proteinden $1,25 \pm 0,2 \mathrm{pmol} / \mathrm{mg}$ proteine yükseltti $(\mathrm{p}<0,05)$. İnkübasyon ortamındaki kisspeptin miktarı $400 \mu \mathrm{M}$ 'a çıkartıldığında ise NA salıverilmesinin daha da arttığı saptand $12,5 \pm 0,08 \mathrm{pmol} / \mathrm{mg}$ protein, $\mathrm{p}<0,001$, Şekil 2A). Doku NA düzeylerinin ise 40 ve $400 \mu \mathrm{M}$ 


\section{Kisspeptin'in Noradrenalin Salıverilmesi Üzerine Etkisi}

kisspeptin konsantrasyonlarında bir miktar azaldığ ancak bu azalmanın anlamlılık seviyesine ulaşmadığ görüldü ( $p>0,05$, Şekil 2B ve Şekil 2C).

Yetişkin sıçanlardan elde edilen veriler değerlendirildiğinde, $40 \mu \mathrm{m}$ konsantrasyonda kisspeptinin NA salıverilmesini $3,22 \pm 0,2 \mathrm{pmol} / \mathrm{mg}$ protein'e, $400 \mu \mathrm{m}$ dozunda ise $3,82 \pm 0,4 \mathrm{pmol} / \mathrm{mg}$ protein'e yükselttiği saptandı (her iki kisspeptin konsantrasyonu için de $\mathrm{p}<0,001$; Şekil 2A). Doku NA düzeylerinin ise 400 $\mu \mathrm{m}$ kisspeptin ile anlamlı olarak arttığı görüldü $(\mathrm{p}<0.001$, Şekil 2B ve Şekil 2C).

Kisspeptinin preoptik dilimlerde NA salvverilmesi üzerine olan etkisinde ekstrasellüler $\mathrm{Ca}^{+2}$ 'un rolü:

Kisspeptinin neden olduğu NA salıverilmesinde ekstrasellüler $\mathrm{Ca}^{2+}$, un rolü adölesan sıçanlardan hazırlanan preoptik dilimlerde test edildi ve ölçülen değerler kontrol koşullarda saptanan NA salıverilme miktarlarına göre yüzde değişim olarak hesaplandı. Buna göre inkübasyon ortamından ekstrasellüler $\mathrm{Ca}^{2+}$, un çıkartılması bazal NA salıverilmesini $\% 19,7 \pm 2,5$, ( $\mathrm{p}>0.05), 400 \mu \mathrm{M}$ kisspeptin'in neden olduğu NA salıverilmesini ise anlamlı olarak azaldığı gözlendi $(\% 153,3 ; \mathrm{p}<0.001$, Şekil 3).

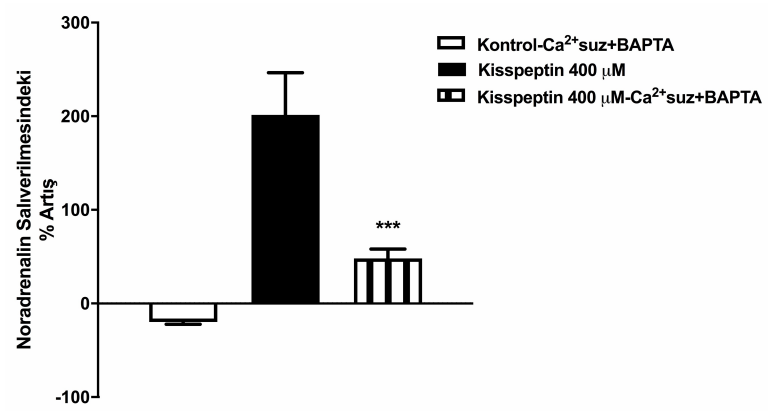

Şekil 3.

$\mathrm{Ca}^{2+}$ un kisspeptin ile indüklenen NA salvverilmesi üzerine etkisinin adölesan dişi sıçanlarda değerlendirilmesi

Adölesan sıçanlardan hazırlanan beyin dilimlerinin kisspeptin ile 1 saatlik normal Krebs ve $\mathrm{Ca}^{2+}$ suz Krebs+BAPTA çözeltisinde inkübasyon sonrası ortama salıverilen NA düzeyleri elektrokimyasal detektörlü HPLC aracılığı ile ölçüldü. Data ortalama \pm standart hata olarak sunuldu $(\mathrm{n}=7) .{ }^{* * *} \mathrm{p}<0.001$ Kisspeptin $400 \mu \mathrm{M}$ grubunun Kisspeptin $400 \mu \mathrm{M}-\mathrm{Ca}^{+2}$ suz-BAPTA grubuna göre anlamlı.

\section{Tartışma ve Sonuç}

Noradrenerjik sistemin GnRH salıverilmesinin regülasyonunda önemli bir role sahip olduğu bilinmekte$\operatorname{dir}^{27}$. A1, A2 ve A6 noradrenerjik hücre gruplar1 GnRH nöronlarının perikarya ve terminallerinde yerleşim gösterirler ve buradan MPOA ve medial bazal hipotalamusa projeksiyon yaparlar ${ }^{28,29}$. NA salıverilmesi ile ilgili çalışmalarda, ovariektomize sıçanlarda proestrus fazında LH dalgalanmasından hemen önce NA salıverilmesinin arttığ bildirilmiştir $^{30,31}$. GnRH nöronlarının adrenerjik reseptörlere sahip olduğu bilgisi de literatürde mevcuttur ${ }^{34,48}$. Bu bilgilere ek olarak, NA sentez inhibisyonunun ${ }^{32,33}$, alfa-adrenerjik reseptörlerin bloke edilmesinin ${ }^{34,35}$ veya A6 noradrenerjik çekirdeğin 36 elektrolitik lezyonunun sıçanlarda LH artışını baskıladığı da çalışmalar ile ortaya konmuştur. Farelerde yapılan diğer bir çalışmada da A2 ve A6 noradrenerjik hücrelerin GnRH nöronları ile direkt bağlantılı olduğu saptanmıştır ${ }^{49}$. Elektrofizyoloji çalışmaları ile NA'in GnRH nöron aktivitesi üzerinde direk bir etkisinin olduğu da gösterilmiştir $^{37}$. Bütün bu bulgular noradrenerjik sistemin GnRH salıverilmesinin regülasyonunda oldukça önemli bir role sahip olduğunu açık bir şekilde ortaya koymaktadır.

Kisspeptin ile bunun reseptörü olan GPR54'ün GnRH ve LH salıverilmelerinin regülasyonunda önemli bir role sahip olduğu özellikle son 10 yıldır yapılan çalışmalar ile gösterilmiştir ${ }^{2-6}$. Kisspeptin preoptik bölgedeki GnRH nöronlarını stimüle ederek GnRH salıverilmesini arttırır. Bu stimülasyonun, insan ve hayvanlarda pubertal gelişimin başlaması ve üreme fonksiyonları için gerekli ve temel bir fizyolojik fonksiyon olduğu araştırmacılar tarafindan ortaya konmuştur ${ }^{3-7}$. Kisspeptinlerin pubertede ve hipotalamus-hipofizgonadal aksdaki kritik rollerinin aydınlatılması sonrası, infertilite ve üreme bozukluklarının tedavisinde yeni bir potansiyel terapötik hedef olarak görülmeye başlanmıştır ${ }^{4}$. Kisspeptinin GnRH salıverilmesi üzerinde sadece direkt etkili olmadığı, bazı düzenleyici mekanizmalar aracılığı ile GnRH salıverilmesi üzerinde indirekt etkisinin olabileceği bildirilmiştir ${ }^{38}$. Bu çalışmalar detaylı incelendiğinde, GnRH salıverilmesi üzerinde etkili nöropeptid $\mathrm{Y}^{39}$, agouti ilişkili protein ${ }^{40}$ ve melanosit stimüle edici hormon ${ }^{41}$ gibi nöropeptidlerin kisspeptin ile direkt veya indirekt ilişkisinin olabileceği görülmektedir. Bu çalışmalara ek olarak nörotransmitterler ile ilgili yapılan çalışmalarda, kisspeptinin glutamat ${ }^{42}, \mathrm{GABA}^{43}$ ve serotonin ${ }^{50}$ gibi nörotransmitterler ile direkt veya indirekt ilişkisi olduğu rapor edilmiştir

NA ve kisspeptin ilişkisi literatürde detaylı incelendiğinde, Fernandois ve arkadaşlarının yaptığı çalışmada yaş ile beraber sıçan yumurtalıklarında kisspeptin ekspresyonunun anlamlı olarak arttığı gösterilmiştir. Bununla birlikte yumurtalık NA düzeylerinin de yaş ile beraber arttığı ve bu artışın kisspeptin artışı ile yüksek korelasyon gösterdiği ortaya konmuştur ${ }^{44}$. Fernandois ve arkadaşlarının yaptığı bir diğer çalışmada ise beta adrenerjik blokerlerin yumurtalık kisspeptin ekspresyonunu azalttığı bulgusu ${ }^{45}$, kisspeptin ile noradrenerjik sistem arasındaki ilişki olabileceğini göstermiştir. Diğer taraftan alfa-1 antagonist prazosinin sıçanlarda MPOA'da kisspeptin ve GnRH ekspresyonunu azalttığı gösterilmiştir ${ }^{46}$. Yuka- 


\section{Z. Gül ve R.L. Büyükuysal}

rıda özetlenen konu ile ilgili çalışmalar bu iki sistemin ilişkili olabileceğini göstermesine rağmen, kisspeptinin NA salıverilmesi üzerine direkt etkisi olup olmadığına dair herhangi bir çalışma bulunmamaktadır.

Çalışmamızdaki bulgulardan ilki MPOA'daki spontan NA salıverilmesinin ve doku düzeylerinin gelişimsel dönemle ilişkili olarak arttığının gösterilmesidir. Bu bulgu literatürdeki daha önceki çalışmalar ile uyumludur $^{27-31,44,45}$. Yaş ile beraber MPOA'da kisspeptin ekspresyonunun değişimi ile ilgili literatürde herhangi bir çalışma olmamasına rağmen yumurtalıklarda yaş ile birlikte kisspeptin ekspresyonunun arttığı gösterilmiştir $^{44,46}$. Çalışmamızdaki diğer bir önemli bulgu da adölesan ve yetişkin sıçanlardan (fakat prepubertal değil) elde edilen dilimlerin kisspeptin ile inkübasyonu sonucu NA salıverilmesinin artmış olmasıdır. Ancak bu artışın bazal NA salıverilmesine göre yüzdesi hesaplandığında en yüksek yüzde artışın adölesan grupta meydana gelmiş olmasıdır. Bu bulguların 1şı̆̆ında adölesan MPOA'daki noradrenerjik nöronların kisspeptine karşı daha duyarlı olduğu söylenebilir. Kisspeptin ile NA salıverilmesi adölesan ve yetişkin sıçanlarda artmasına rağmen, doku NA düzeyleri sadece yetişkin sıçanlarda değişiklik göstermiştir. Pre-pubertal ve adölesan sıçanlarda kisspeptin ile doku NA düzeylerinin bir miktar azaldığı ancak bu azalışın anlamlı olmadığı, yetişkin sıçanlarda ise düşük doz kisspeptin de değişmeyip yüksek doz kisspeptin ile arttığını gözlemledik. Bu durum ile, kisspeptinin pre-pubertal ve adölesan sıçanlarda veziküllerde biriken NA salıverilmesini uyardığını, ancak yetişkin sıçanlarda hem salıverilmeyi, hem de NA sentezini arttırdığı ileri sürülebilir. Ancak bu hipotezin ekspresyon çalışmaları ile desteklenmesi gerekmektedir. Diğger taraftan kisspeptin ile uyarılan NA salıverilmesinin, ekstrasellüler $\mathrm{Ca}^{2+}$ iyonlarına bağlı olması, salıverilmenin veziküler olabileceğini düşündürmekle, mekanizmanın tam olarak aydınlatılması (endojen firing veya voltaja duyarlı $\mathrm{Na}^{+}$kanallarının rolü gibi) için daha fazla çalışmalara ihtiyaç duyulmaktadır.

Beyin dilimlerini kullanarak daha önce yaptığımız çalışmaların bir kısmında, cinsiyete bağlı bir farklılık görmediğimiz için dişi sıçanları kullanmıştık ${ }^{25,51}$. Her ne kadar, dişi siçanlarda menstural siklusun hipotalamus nörotransmitter düzeylerinin değiştirdiği gösterilmişse $\mathrm{de}^{50}$, in vitro beyin dilimlerinde siklusun nörotrasnmitter salıverilmesi etkileyebileceği ile ilgili herhangi bir çalıșma bulunmamaktadır. Siklusun in vitro nörotransmitter salıverilmesi üzerinde olası bir etkisinin olabileceği düşünülürse, bu çalışmada kullanılan yetişkin sıçanların sikluslarının göz ardı edilmiş olması, çalışma sonuçlarının yorumlanmasını sınırlayan bir olasılık gibi görülmektedir. Bu nedenle, konunun aydınlatılması için daha fazla çalışma yapılması gerektiği kanısındayız.
Sonuç olarak bu çalışma, kisspeptinin NA salıverilmesini direkt olarak arttırabildiğini göstermesi ve bu etkinin kisspeptin ile noradrenerjik sistemin direkt ilişkisinin ortaya koyan literatür bilgileri ile uyumlu olması açısından önemlidir. Hipotalamo-hipofizergonadal aks üzerinde kisspeptin molekülünün rolünün daha detaylı bir şekilde incelenerek ortaya konması, kisspeptin reseptör mutasyonlu hastalarda yeni tedavi seçeneklerinin araştırılması veya puperteden sorumlu hormonların salgılanmasının düzenlemeleri konusunda yeni çalışmalara 1şık tutabilir.

Etik Kurul Onay Bilgisi:

Onaylayan Kurul: Uludağ Üniversitesi Hayvan Deneyleri Yerel Etik Kurulu.

Onay Tarihi: 16.02 .2016

Karar No: 216-03/05

\section{Kaynaklar}

1. Herbison AE. Physiology of the adult gonadotropin-releasing hormone neuronal network. In: Plant T, Zeleznik A, eds. Knobil and Neill's Physiology of Reproduction. 4th ed. London: Elsevier 2015;399-467.

2. Seminara SB, Messager S, Chatzidaki EE, et al. The GPR54 gene as a regulator of puberty. N Engl J Med 2003;349:161427

3. Dhillo WS. Kisspeptin: a novel regulator of reproductive function. J Neuroendocrinol 2008;20:963-70.

4. Seminara SB, Crowley WF Jr. Kisspeptin and GPR54: discovery of a novel pathway in reproduction. $\mathrm{J}$ Neuroendocrinol 2008;20:727-31.

5. Jayasena CN, Dhillo WS, Bloom SR. Kisspeptin and the control of gonadotropin secretion in humans. Peptides 2009;30:76-82

6. de Roux N, Genin E, Carel JC, Matsuda F, Chaussain JL, Milgrom E. Hypogonadotropic hypogonadism due to loss of function of the KiSS1-derived peptide receptor GPR54. Proc Natl Acad Sci U S A 2003;100:10972-6.

7. Dungan HM, Gottsch ML, Zeng H,et al. The role of kisspeptin GPR54 signaling in the tonic regulation and surge release of gonadotropin-releasing hormone/luteinizing hormone. J Neurosci 2007; 27(44):12088-95

8. Herbison AE. Estrogen positive feedback to gonadotropinreleasing hormone $(\mathrm{GnRH})$ neurons in the rodent: the case for the rostral periventricular area of the third ventricle (RP3V). Brain Res Rev. 2008;57(2):277-287.

9. Han S-K, Gottsch ML, Lee KJ, et al. Activation of gonadotropin releasing hormone neurons by kisspeptin as a neuroendocrine switch for the onset of puberty. J Neurosci. 2005;25(49):11349-56.

10. Messager S, Chatzidaki EE, Ma D, et al. Kisspeptin directly stimulates gonadotropin releasing hormone release via $\mathrm{G}$ protein-coupled receptor 54. Proc Natl Acad Sci U S A 2005;102:1761-6.

11. Matsui H, Takatsu Y, Kumano S, Matsumoto H, Ohtaki T. Peripheral administration of metastin induces marked gonadotropin release and ovulation in the rat. Biochem Biophys Res Commun 2004;320:383-8.

12. Navarro VM, Castellano JM, Fernández-Fernández R, et al. Effects of KiSS-1 peptide, the natural ligand of GPR54, on follicle-stimulating hormone secretion in the rat. Endocrinology 2005;146:1689-97. 


\section{Kisspeptin'in Noradrenalin Salıverilmesi Üzerine Etkisi}

13. Shahab M, Mastronardi C, Seminara SB, Crowley WF, Ojeda SR, Plant TM. Increased hypothalamic GPR54 signaling: a potential mechanism for initiation of puberty in primates. Proc Natl Acad Sci U S A 2005;102:2129-34.

14. Sawyer CH. First Geoffrey Harris Memorial lecture. Some recent developments in brain-pituitary-ovarian physiology. Neuroendocrinology 1975; 17: 97-124.

15. Weiner RI, Ganong WF. Role of brain monoamines and histamine in regulation of anterior pituitary secretion. Physiol Rev 1978; 58: 905-976.

16. Gallo RV. Neuroendocrine regulation of pulsatile luteinizing hormone release in the rat. Neuroendocrinology 1980; 30: 122131.

17. Kalra SP. Neural circuitry involved in the control of LHRH secretion: a model for preovulatory LH release. Front Neuroendocrinol 1986; 9: 31-75.

18. Ramirez VD, Ramirez AD, Slamet W, Nduka E. Functional characteristics of the luteinizing hormone-releasing hormone pulse generator in trial, unrestrained female rabbits: activation by norepinephrine. Endocrinology 1986; 118: 2331-2339.

19. Terasawa E, Krook C, Hei DL, Gearing M, Schultz NJ, Davis GA. Norepinephrine is a possible neurotransmitter stimulating pulsatile release of luteinizing hormone-releasing hormone in the rhesus monkey. Endocrinology 1988; 123: 1808-1816.

20. Pau KY, Hess DL, Kaynard AH, Ji WZ, Gliessman PM, Spies HG. Suppression of mediobasal hypothalamic gonadotropinreleasing hormone and plasma luteinizing hormone pulsatile patterns by phentolamine in ovariectomized rhesus macaques. Endocrinology 1989; 124: 891-898.

21. Pau KY, Gliessman PM, Oyama T, Spies HG. Disruption of GnRH pulses by anti-GnRH serum and phentolamine obliterates pulsatile LH but not FSH secretion in ovariectomized rabbits. Neuroendocrinology 1991; 53: 382391.

22. Kafa MI, Eyigör Ö. Kisspeptins and Kisspeptin Neurons: Effects on Reproductive System and Hypothalamic Localizations. Uludağ Tıp Fakültesi Dergisi 2011:37 (1) 53-60,

23. Francis Pau KY, Cyrus JL, Cowles A, Yang SP, Hess DL, Spies HG. Possible Involvement of Norepinephrine Transporter Activity in the Pulsatility of Hypothalamic GonadotropinReleasing Hormone Release: Influence of the Gonad. Journal of Neuroendocrinology 1998; 10:21-29.

24. Tassigny X, Ackroyd K.J, Chatzidaki E.E, Colledge WH Kisspeptin Signaling Is Required for Peripheral But Not Central Stimulation of Gonadotropin-Releasing Hormone Neurons by NMDA. The Journal of Neuroscience, June 23, 2010. 30(25):8581-8590.

25. Gul Z, Buyukuysal MC, Buyukuysal RL. Brain slice viability determined under normoxic and oxidative stress conditions: involvement of slice quantity in the medium. Neurological Research 2020;42:228-238.

26. Gul Z, Demircan C, Bagdas D, Buyukuysal RL. Aging protects rat cortical slices against to oxygen-glucose deprivation induced damage. International Journal of Neuroscience 2020;1 9.

27. Herbison AE. Noradrenergic regulation of cyclic GnRH secretion. Rev Reprod 1997;2(1):1-6.

28. Helena CVV, Szawka RE, Anselmo-Franci JA. Noradrenaline involvement in the negative-feedback effects of ovarian steroids on luteinising hormone secretion. J Neuroendocrinol 2009;21(10):805-12.

29. Haywood SA, Simonian SX, van der Beek EM, Bicknell RJ, Herbison AE. Fluctuating estrogen and progesterone receptor expression in brainstem norepinephrine neurons through the rat estrous cycle. Endocrinology 1999;140(7):3255-63.

30. Szawka RE, Franci CR, Anselmo-Franci JA. Noradrenaline release in the medial preoptic area during the rat oestrous cycle: temporal relationship with plasma secretory surges of prolactin and luteinising hormone. J Neuroendocrinol 2007;19(5):374382 .

31. Szawka RE, PoletiniMO, Leite CM, et al. Release of norepinephrine in the preoptic area activates anteroventral periventricular nucleus neurons and stimulates the surge of luteinizing hormone. Endocrinology 2013;154(1):363-374

32. Gnodde HP, Schuiling GA. Involvement of catecholaminergic and cholinergic mechanisms in the pulsatile release of $\mathrm{LH}$ in the longterm ovariectomized rat. Neuroendocrinology $1976 ; 20(3): 212-23$

33. Kalra PS, Kalra SP, Krulich L, Fawcett CP, McCann SM. Involvement of norepinephrine in transmission of the stimulatory influence of progesterone on gonadotropin release. Endocrinology 1972;90(5):1168-76.

34. 34.Le W, Berghorn KA, Smith MS, Hoffman GE. 1-Adrenergic receptor blockade blocks LH secretion but not LHRH cFos activation. Brain Res 1997;747(96):236-45.

35. Weick RF. Acute effects of adrenergic receptor blocking drugs and neuroleptic agents on pulsatile discharges of luteinizing hormone in the ovariectomized rat. Neuroendocrinology 1978;26(2):108-17

36. Anselmo-Franci JA, Franci CR, Krulich L, Antunes-Rodrigues J, McCann SM. Locus coeruleus lesions decrease norepinephrine input into the medial preoptic area and medial basal hypothalamus and block the LH, FSH and prolactin preovulatory surge. Brain Res 1997;767(2):289-296.

37. Han S-K, Herbison AE. Norepinephrine suppresses gonadotropin releasing hormone neuron excitability in the adult mouse. Endocrinology 2008;149(3):1129-35.

38. Marraudino M, Miceli D, Farinetti A, Ponti G, Panzica G, Gotti S. Kisspeptin innervation of the hypothalamic paraventricular nucleus: sexual dimorphism and effect of estrous cycle in female mice. J Anat 2017;230:775-86.

39. Navarro VM, Castellano JM, McConkey SM, et al. Interactions between kisspeptin and neurokinin $\mathrm{B}$ in the control of $\mathrm{GnRH}$ secretion in the female rat. Am J Physiol Endocrinol Metab 2011;300:E202-E210.

40. Padilla SL, Qiu J, Nestor CC, et al. AgRP to Kiss1 neuron signaling links nutritional state and fertility. Proc Natl Acad Sci USA Biol Sci 2017: 201621065

41. Manfredi-Lozano M, Roa J, Ruiz-Pino F, et al. Defining a novel leptin-melanocortin-kisspeptin pathway involved in the metabolic control of puberty. Mol Metab 2016;5:844-57.

42. Min L, Adeola O, Carroll RS, Kaiser UB. Glutamate Acts as a Cofactor in the Activation of KISS1R by Kisspeptin, Signaling Originating from Membrane Receptors. Endocrine Society 2013; SUN-402-SUN-402.

43. Cheong RY, Czieselsky K, Porteous R, Herbison AE. Expression of ESR1 in glutamatergic and GABAergic neurons is essential for normal puberty onset, estrogen feedback, and fertility in female mice. J Neurosci 2015;35:14533-43.

44. Fernandois D, Na E, Cuevas F, Cruz G, Lara H, Paredes AH. Kisspeptin is involved in ovarian follicular development during aging in rats. J Endocrinol 2016;228:161-70.

45. Fernandois D, Cruz G, Na EK, Lara HE, Paredes AH. Kisspeptin level in the aging ovary is regulated by the sympathetic nervous system. J Endocrinol 2017;232:97-105.

46. Kalil B, Ribeiro AB, Leite CM, et al. The Increase in Signaling by Kisspeptin Neurons in the Preoptic Area and Associated Changes in Clock Gene Expression That Trigger the LH Surge in Female Rats Are Dependent on the Facilitatory Action of a Noradrenaline Input. Endocrinology 2016;157:323-35.

47. Du XJ, Bobik A, Esler MD, Dart MA. Effects of Intracellular $\mathrm{Ca} 2+$ Chelating on Noradrenaline Release in Normoxic and Anoxic Hearts. Clinical and Experimental Pharmacology and Physiology 1997;24:819-23. 


\section{Z. Gül ve R.L. Büyükuysal}

48. Lowry OH, Rosebrough NJ, Farr AL. Protein measurement with the Folin phenol reagent. Journal of Biological Chemistry 1951;193: 265-275.

49. Campbell RE, Herbison AE. Definition of brainstem afferents to gonadotropin-releasing hormone neurons in the mouse using con- ditional viral tract tracing. Endocrinology 2007;148:588490.
50. Barth C, Villringer A, Sacher J. Sex hormones affect neurotransmitters and shape the adult female brain during hormonal transition periods. Front Neurosci 2015:37:1-20.

51. Demircan C, Gul Z, Buyukuysal RL. High glutamate attenuates S100B and LDH outputs from rat cortical slices enhanced by either oxygen-glucose deprivation or menadione. Neurochemical research 2014:39:1232-1244. 